\title{
Pracownicy i ich motywacje a wyzwania w zarządzaniu zasobami ludzkimi
} Employees and their motivations and challenges
In managing human resources prof. dr hab. inż. Halina Podsiadło

Politechnika Warszawska, Wydział Inżynierii Produkcji ORCID: 0000-0002-2202-6215 e-mail: h.podsiadlo@wip.pw.edu.pl inż. Aleksander Balik

\begin{abstract}
Streszczenie Pracownicy poszukują najlepszych miejsc pracy a pracodawcy najlepszych pracowników — to oczywisty truizm. Obecna sytuacja na rynku pracy sprawia, że podmioty zatrudniające muszą nie tylko szukać sposobów skutecznej rekrutacji pracowników, ale i utrzymania intratnej współpracy z już zatrudnionymi. Pracownicy oczekują więcej, a dawne dodatkowe profity stają się standardem. Ogłoszenia o pracę zachęcają pakietami motywacyjnymi, mimo tego brakuje rąk do pracy. Autorzy przedstawiają obecną sytuację na rynku pracy w Polsce i wyzwania jakie ona niesie dla zarządzania zasobami ludzkimi.
\end{abstract}

Słowa kluczowe: zatrudnienie, motywacja, zarządzanie, bezrobocie, rekrutacja.

Summary Employees are looking for the best jobs and the best employers are employees — truism — the current situation exerts new solutions on the employers who want to start and maintain profitable cooperation. Employees expect more and the old additional goods become a standard. Job advertisements are encouraged by motivation packages, despite this good employees are missing. The article contains a description of basic concepts, statistical data, historical background, scientific achievements and describes the present situation on the labor market.

Keywords: employment, motivation, management, unemployment, recruitment.

JEL: K31

Str. 23-27

\section{Bibliografia}

Bieniok, H. (red.). (2006). System zarządzania zasobami ludzki- mi przedsiębiorstwa. Katowice.

Borkowska, S. (1985). System motywowania w przedsiębiorstwie. Warszawa: Polskie Wydawnictwo Ekonomiczne.

Godziszewski, B. Haffer, M. Stankiewicz, M. J. Sudoł, S. (2011). Przedsiębiorstwo. Teoria i praktyka zarzadzania. Warszawa: Polskie Wydawnictwo Ekonomiczne.

Juchnowicz, M. (2012). Zaangażowanie pracowników. Warszawa: Polskie Wydawnictwo Ekonomiczne.

Ministerstwo Rodziny, Pracy i Polityki Społecznej. (2018). Rynek pracy w Polsce w 2017 roku. Ministerstwo Rodziny, Pracy i Polityki Spolecznej. Departament Rynku Pracy.

Pietroń-Pyszczek, A. (2007). Motywowanie pracowników. Wskazówki dla menedżerów. Wrocław: Wydawnictwo MARINA.

Sidor-Rządkowska, M. (2000). Ksztaltowanie nowoczesnych systemów ocen pracowników. Kraków.

Sikora, J. (2000). Motywowanie pracowników. Bydgoszcz.

Witucki, M., http://extra.innpoland.pl/rynek-pracownika-to-mit (15.04.2018). 